\title{
The Efficacy of the FOMC's Zero Interest Rate Policy
}

\author{
Daniel L. Thornton, Vice President and Economic Adviser
}

$S$ ince the late 1980s the Federal Open Market Committee (FOMC) has conducted monetary policy primarily by setting a target for the nominal overnight federal funds rate. In late 2008 the FOMC set the target at zero. It has since indicated that it expects the target to remain at zero until late 2014. Should this happen, the funds rate will have been zero for nearly six years. This essay suggests the possibility that the net effect of such a prolonged zero interest rate policy might be harmful for economic growth.

The so-called interest rate channel of policy works by adjusting the real rate of interest relative to what it would be if the FOMC did not increase or decrease its target for the funds rate. Reducing the funds rate target reduces real longer-term rates, which provides an incentive for businesses to increase capital investment, but only to the extent that the policy action reduces longer-term real rates.

The reduction in the real rate also affects consumer spending through what economists call income and substitution effects. The lower interest rate increases the price of future consumption, causing individuals to increase current consumption and reduce current saving - the substitution effect. The lower rate also reduces current interest income, which induces individuals to save more and consume lessthe income effect. Consequently, consumption can increase or decrease depending on the relative magnitudes of the income and substitution effects.

Persistently lower real rates can have an indirect effect on consumption because they induce individuals to take on riskier investments. Standard portfolio theory sees investors as balancing the risk of holding a particular set of assets against the average portfolio return. The desired portfolio is one that minimizes the risk for a given average return. Reducing the real rate of interest on bonds (especially low-risk bonds) relative to all other investments induces investors to hold riskier portfolios to increase the average return. Hence, in addition to the direct effect on current income, persistently low real interest rates might motivate individuals to save more in an attempt to compensate for lower expected future returns and higher risk. This effect

is likely to intensify the longer real rates are abnormally low.

Is the net effect of the zero interest policy on consumption positive or negative? The accompanying chart suggests that it could be negative. Interest income declined by $\$ 400$ billion from September 2008 to October 2009 and has since been relatively constant. Indeed, the chart shows that interest income as a percent of personal income declined from its 2008:Q3 peak of 9.9 percent to 6.5 percent in 2012:Q2, a level not seen since 1969. The chart also shows that there was a marked increase in the saving rate at the outset of the 2007-09 recession. While the saving rate declined from its immediate post-recession peak after the implementation of the zero interest rate policy, the average saving rate from 2009:Q1 through 2012:Q2 was 3.5 percent compared with 2.33 percent from 2000:Q1 through 2008:Q4.

\section{If investment spending is sufficiently insensitive to interest rate changes and the effect of Fed actions on interest rates is sufficiently weak, the net effect of the persistent zero interest rate policy could be negative.}

Even if the effect of the zero interest rate policy on consumption has been negative, the total effect could be positive because of the positive effect on investment spending. The problem here is that the interest rate channel of monetary policy has been thought to be relatively weak for a variety of reasons: (i) Policy actions have the largest effect on short-term rates, but longer-term rates, which are much less affected, matter for most spending decisions; (ii) rates on credit cards, revolving lines of credit, and other conditions that would affect consumer spending are relatively insensitive to changes in the policy rate; (iii) businesses say that interest expense is a relatively minor consideration when making investment decisions-the most important consideration is the expected stream of income from the 


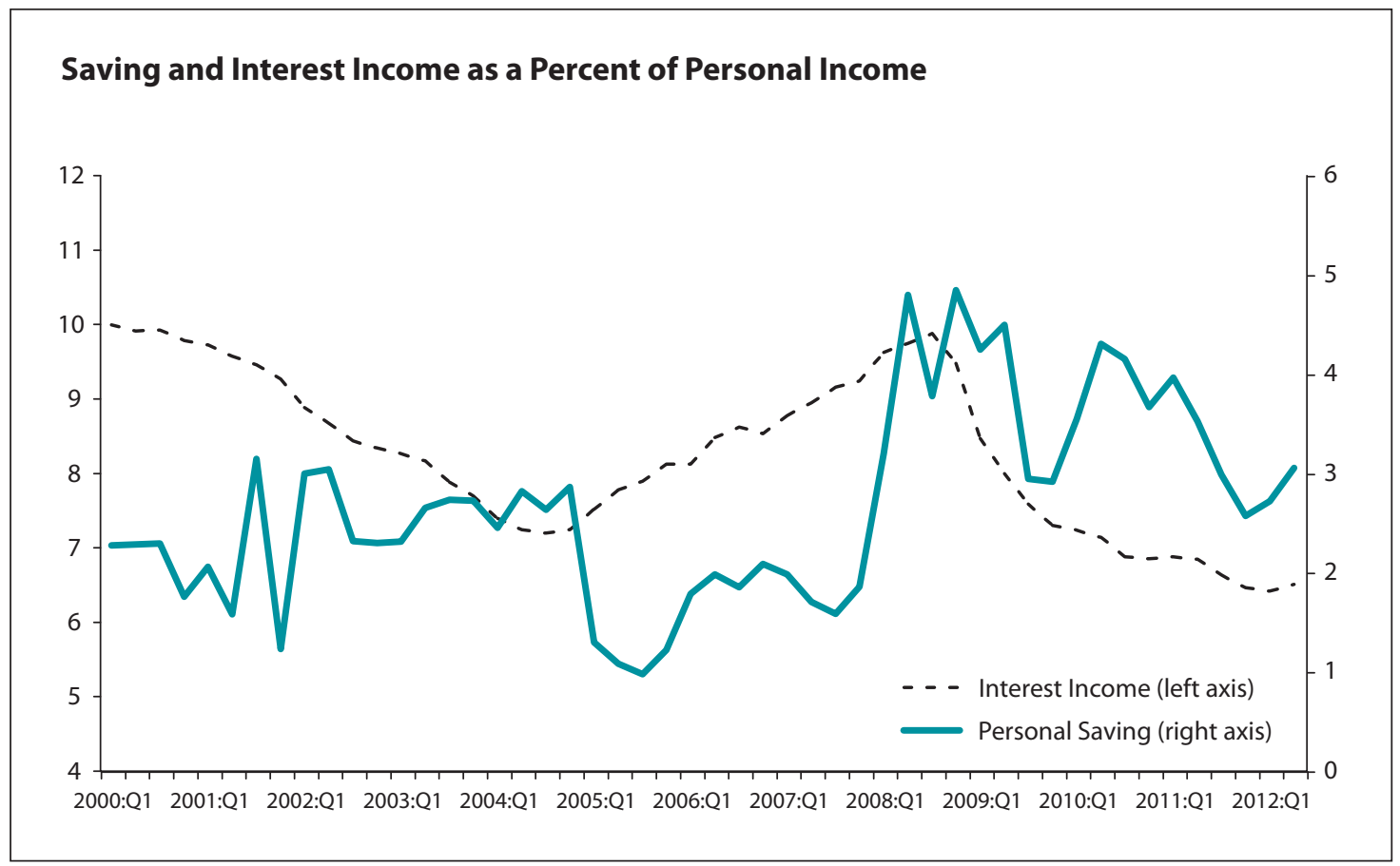

investment; and (iv) much corporate investment is completely or partially internally financed.

The weakness of the interest rate channel was acknowledged by Bernanke and Gertler (1995), who noted that "empirical studies of supposedly 'interest-sensitive' components of aggregate spending have in fact had great difficulty in identifying a quantitatively important effect." 1 Indeed, in an attempt to account for what they believed to be the apparent potency of monetary policy, a number of economists have considered the role of imperfect information and other frictions in the credit market. Collectively, these mechanisms are known as the credit channel of monetary policy.

Furthermore, several economists have questioned the extent to which the Fed can influence interest rates, in part, because the effect of the Fed's lending and investing actions on the supply of credit has been small historically. ${ }^{2}$ Other things the same, the smaller the effect of Fed actions on the supply of credit, the smaller the effect on interest rates. However, since Lehman Brothers announced bankruptcy in mid-September 2008, the Fed has significantly increased its contribution to the total supply of credit from about $\$ 800$ billion to about $\$ 2.6$ trillion. But $\$ 1.5$ trillion of the
$\$ 1.8$ trillion increase in the supply of credit is held by banks as excess reserves. Hence, the net increase in the supply of credit to the public is only about $\$ 300$ billion, a small increase relative to the $\$ 55$ trillion domestic credit market and even smaller relative to the economically relevant international credit market.

In any event, if investment spending is sufficiently insensitive to changes in the interest rate and the effect of the Fed's actions on interest rates is sufficiently weak, the net effect of the FOMC's persistent zero interest rate policy could hinder economic growth.

\section{Notes}

${ }^{1}$ Ben S. Bernanke and Mark Gertler. "Inside the Black Box: The Credit Channel of Monetary Policy Transmission." Journal of Economic Perspectives, 1995, 9(4), pp. 27-48.

${ }^{2}$ For example, see Eugene F. Fama, "Does the Fed Control Interest Rates?" Chicago Booth Paper No. 12-23; Daniel L. Thornton, "Monetary Policy: Why Money Matters, and Interest Rates Don't," Federal Reserve Bank of St. Louis Working Paper 2012-020A, and "Does The Fed Control Short-Term Interest Rates?” Federal Reserve Bank of St. Louis Monetary Trends, December 1995; and Benjamin M. Friedman, "The Future of Monetary Policy: The Central Bank as an Army with Only a Signal Corps?" International Finance, 1999, 2(3), pp. 321-38. 